\title{
IGF-I, IGF-II, IGFBP2, IGFBP3 and acid-labile subunit (ALS) in colorectal cancer patients before surgery and during one year follow up in relation to age
}

\author{
Sztefko $\mathrm{K}^{1^{*}}$, Hodorowicz-Zaniewska $\mathrm{D}^{2}$, Popiela $\mathrm{T}^{2}$, Richter $\mathrm{P}^{2}$ \\ 1 Department of Clinical Biochemistry, Paediatric Institute, Jagiellonian University, Krakow, Poland \\ 2 Department of Surgery 1, College of Medicine, Jagiellonian University, Krakow, Poland
}

\author{
* CORRESPONDING AUTHOR: \\ Department of Clinical Biochemistry, Paediatric Institute, \\ College of Medicine, Jagiellonian University, \\ ul. Wielicka 265, \\ 30-663 Kraków, Poland \\ tel/fax: +48-12-658-06-81 \\ e-mail: misztefk@cyf-kr.edu.pl (Krystyna Sztefko)
}

\author{
Received 30.12.2008 \\ Accepted 15.04.2009 \\ Advances in Medical Sciences \\ Vol. 54(1) $\cdot 2009 \cdot$ pp 51-58 \\ DOI: $10.2478 / \mathrm{v} 10039-009-0017-4$ \\ (C) Medical University of Bialystok, Poland
}

\begin{abstract}
Purpose: To investigate the changes of IGF system in colon cancer patients in relation to age, the serum IGF-I, IGF-II, IGFBP2, IGFBP3 and ALS were measured by immunochemistry before surgery, as well as one and six months after surgery. Material and Methods: One hundred and twenty six patients were included into the study: group I ( $<50$ yrs, N=21); group II ( 50 to $<55 \mathrm{yrs}, \mathrm{N}=16)$; group III $(55$ to $<65 \mathrm{yrs}, \mathrm{N}=34)$; group IV ( 65 to $<75 \mathrm{yrs}, \mathrm{N}=42)$ and group V ( $\geq 75 \mathrm{yrs}, \mathrm{N}=13)$.

Results: Before surgery: only the mean value of IGF-I concentration in group I was significantly higher as compared to group $\mathrm{V}(\mathrm{p}<0.01)$. One month after surgery: 1$)$ a decrease in the mean values of IGF-I, IGF-II, IGFBP3 and ALS levels was observed, but only for IGF-II (groups II-V), IGFBP3 (groups II-V) and ALS (groups III-V) the changes were significant; 2) the mean value of ALS level in group I was higher as compared to group III-V ( $p<0.05$ to 0.02 ); 3 ) higher mean values of IGF-I/alb, IGFBP3/alb and ALS/alb were noted for group I as compared to group V ( $p<0.01$ to 0.001 ); 4) the mean levels of IGFBP2 were significantly lower in group I as compared to groups II, III, IV and $\mathrm{V}$ ( $\mathrm{p}<0.001$ in all cases).

Conclusions: In colon cancer patients IGF-I, IGFBP3 and ALS decrease with age, but the relation between them exists regardless the patient's age and time of observation. Lower IGFBP2 level together with higher IGF-I might contribute to more aggressive course of disease in colon cancer patients below 50 years of age.
\end{abstract}

Key words: IGFI, IGFII, IGFBP2, IGFBP3, ALS, colon cancer

\section{INTRODUCTION}

Epidemiological data link IGF system with the risk of cancer. It has been postulated that IGF-I concentration at the upper normal range and IGFBP3 values at lower normal range predict the subsequent development of colorectal cancer [1]. It is known that aging proceeds more quickly with higher levels of IGF-related signaling [2,3]. The circulating IGFs are bound to IGFBPs, mainly IGFBP3, forming a $150 \mathrm{kDa}$ ternary complex with acid labile subunit (ALS) [4]. It is known that the levels of both IGF-I and IGFBP3 are relatively stable within individuals, but vary considerably between normal individuals because of differences in physical activity, BMI, and diet [5,6]. The binding proteins not only modulate the bioavailability of IGF-I and IGF-II for the receptors, but also greatly prolong the circulating half-life of IGFs. Bioavailability of IGFs is influenced by the levels of specific IGFBPs [7]. IGF-I play a critical role in cellular survival and proliferation. Elevated circulating IGF-I levels have been associated with an increased risk of colorectal cancer. Interactions among insulin, IGF-I and its binding proteins in the context of colorectal carcinogenesis provide a potential mechanism through which the diet and the associated lifestyle factors may increase the risk of this type of cancer.

The results of different studies on IGF axis in colon cancer patients are difficult to compare. This is mainly due to differences concerning the population used and the complexity of molecular mechanisms, which could explain the possible connection of IGFs and their binding proteins not only with carcinogenesis but also with the progression of colorectal 
Table 1. Clinical characteristics of colon cancer patients.

\begin{tabular}{|c|c|c|c|c|c|}
\hline & $\begin{array}{l}\text { Group I } \\
<50 \text { years }\end{array}$ & $\begin{array}{l}\text { Group II } \\
50 \text { to }<55 \text { years }\end{array}$ & $\begin{array}{l}\text { Group III } \\
55 \text { to }<65 \text { years }\end{array}$ & $\begin{array}{c}\text { Group IV } \\
65 \text { to }<75 \text { years }\end{array}$ & $\begin{array}{l}\text { Group } V \\
\geq 75 \text { years }\end{array}$ \\
\hline $\mathrm{N}$ & 21 & 16 & 34 & 42 & 13 \\
\hline $\mathrm{BMI}\left[\mathrm{kg} / \mathrm{m}^{2}\right] \quad$ mean $\pm \mathrm{SE}$ & $25.65 \pm 0.97$ & $26.21 \pm 0.95$ & $26.02 \pm 0.54$ & $25.88 \pm 0.66$ & $24.44 \pm 0.81$ \\
\hline \multicolumn{6}{|l|}{ Sex, N ( \%) } \\
\hline Male & $10(47.6)$ & $13(81.2)$ & $16(47.0)$ & $22(52.4)$ & $9(69.2)$ \\
\hline Female & $11(52.7)$ & $3(18.8)$ & $18(53.0)$ & $20(47.6)$ & $4(30.8)$ \\
\hline \multicolumn{6}{|l|}{ Disease stage: N (\%) } \\
\hline Stage 1 & $2(9.5)$ & $3(18.8)$ & $7(20.6)$ & $10(24.0)$ & $3(23.1)$ \\
\hline Stage 2 & $5(23.8)$ & $5(31.2)$ & $7(20.6)$ & $10(24.0)$ & $3(23.1)$ \\
\hline Stage 3 & $10(47.6)$ & $5(31.2)$ & $9(26.5)$ & $15(36.0)$ & $7(53.8)$ \\
\hline Stage 4 & $4(19.1)$ & $3(18.8)$ & $11(32.3)$ & $7(17.0)$ & 0 \\
\hline \multicolumn{6}{|l|}{ Tumor localization :N (\%) } \\
\hline Colon & $12(57.1)$ & $12(75.0)$ & $19(55.9)$ & $27(64.3)$ & $7(53.8)$ \\
\hline Rectum & $9(42.9)$ & $4(25.0)$ & $15(44.1)$ & $15(35.7)$ & $6(46.2)$ \\
\hline \multicolumn{6}{|l|}{ Grade: N (\%) } \\
\hline 1 & $7(33.3)$ & $8(50.0)$ & $16(47.1)$ & $21(50.0)$ & $3(23.0)$ \\
\hline 2 & $14(66.7)$ & $8(50.0)$ & $18(52.9)$ & $21(50.0)$ & $10(77.0)$ \\
\hline \multicolumn{6}{|l|}{ TPN before surgery $\mathrm{N}(\%)$} \\
\hline Yes & $11(52.4)$ & $4(25.0)$ & $17(50.0)$ & $21(50.0)$ & $6(46.2)$ \\
\hline No & $10(47.6)$ & $12(75.0)$ & $17(50.0)$ & $21(50.0)$ & $7(53.8)$ \\
\hline \multicolumn{6}{|l|}{$\begin{array}{l}\text { Disease progression after } \\
\text { one year: } N(\%)\end{array}$} \\
\hline Stable & $12(57.2)$ & $6(37.5)$ & $11(32.4)$ & $24(57.2)$ & $8(61.5)$ \\
\hline Progression & $2(9.5)$ & $1(5.3)$ & $8(23.5)$ & $9(21.4)$ & $4(30.8)$ \\
\hline Died & $7(33.3)$ & $9(56.2)$ & $15(44.1)$ & $9(21.4)$ & $1(7.7)$ \\
\hline \multicolumn{6}{|l|}{ Albumin [g/l] } \\
\hline Mean \pm SE & $43.7 \pm 2.1$ & $40.8 \pm 1.2$ & $42.6 \pm 1.4$ & $42.0 \pm 1.1$ & $39.7 \pm 1.218$ \\
\hline $95 \% \mathrm{CI}$ of mean & $(39.3-48.1)$ & $(39.8-45.3)$ & $(40.4-46.3$ & $(39.8-44.1)$ & $(37.1-42.3)$ \\
\hline
\end{tabular}

cancer. One of the reasons of inconsistent interpretation is a complex interaction among different factors: physical activity, diet and nutritional status. All these factors may influence the concentrations of IGFs and IGFBPs in the circulation. It is also known that in healthy subjects plasma levels of the components of IGF system are related to age, sex and BMI, and that there are considerable inter-individual and intraindividual variations [8-10]. Pre-analytical and analytical problems connected with the measurement of IGFs and IGFBPs concentrations in blood serum frequently lead to controversial conclusions. Data concerning the relationship between age and serum IGF-I and IGFBP3 levels in a general adult population have been published recently [11], but for patients with colon cancer no such data are available. The data from the literature focus mainly on IGF system long before and at the time of diagnosing adenoma or cancer, but no data exist regarding the IGF system components in colon cancer patients before surgery and during one year follow up in relation to age.

\section{MATERIAL AND METHODS}

One hundred twenty six patients with colorectal cancer (70 men and 56 women) were included in the study. Clinical diagnosis was based on physical examination, colonoscopy, endorectal USG, abdominal CT, and histopathology of tissue specimens according to Astler-Coller classification. Each patient underwent open surgery in order to remove the tumor. According to the UICC/AJCC classification [12,13], there were 25 patients with stage I disease, 30 patients with stage II disease (IIA/IIB: 22/8), 46 patients with stage III disease (IIIA/IIIB/IIIC: 9/10/27) and 25 patients with stage IV disease. In 49 patients the tumor was localized in the colon and in 77 patients the localization was confined mainly to the rectum. In six patients $(4.7 \%)$ two or more tumor localizations were found. All patients with stage IV disease had M1 HEP. Fifty nine patients had total parenteral nutrition (TPN) before surgery. After one year follow up, 61 patients were in stable condition and the remaining 65 patients had a progression of the disease. Eventually 41 of them died. The patients with diabetes mellitus or glucose intolerance based on fasting plasma glucose level and oral glucose tolerance test (OGTT) were excluded from the study. The clinical characteristics of the patients studied is shown in Tab. 1. The study protocol was approved by the local ethics committee. A written informed consent was obtained from each patient.

The mean age of patients was $62.2 \pm 0.98$ years, with 21 patients below 50 years (range 36 to 49 years, group I), 16 patients between 50 and 55 years (range 50 to 54 years, group II), 34 patients between 55 and 65 years (range 55 to 64, group 
Table 2. The mean values, SE and 95\% CI of mean for IGF-I, IGF-II, IGFBP2, IGFBP3 and ALS in colon cancer patients before surgery in relation to age.

\begin{tabular}{|c|c|c|c|c|c|}
\hline & $\begin{array}{l}\text { Group I } \\
<50 \text { years }\end{array}$ & $\begin{array}{l}\text { Group II } \\
50 \text { to }<55 \text { years }\end{array}$ & $\begin{array}{l}\text { Group III } \\
55 \text { to }<65 \text { years }\end{array}$ & $\begin{array}{c}\text { Group IV } \\
65 \text { to }<75 \text { years }\end{array}$ & $\begin{array}{l}\text { Group } V \\
\geq 75 \text { years }\end{array}$ \\
\hline $\mathrm{N}$ & 21 & 16 & 34 & 42 & 13 \\
\hline \multicolumn{6}{|l|}{ IGF-I [ng/ml] } \\
\hline Mean \pm SE & $194.2 \pm 15.68$ & $199.8 \pm 20.96$ & $177.8 \pm 10.95$ & $176.0 \pm 9.96$ & $136.4 \pm 13.52 *$ \\
\hline $95 \% \mathrm{CI}$ of mean & $163.5-228.9$ & $155.2-244.5$ & $155.6-200.1$ & $155.9-196.1$ & $107.9-165.9$ \\
\hline \multicolumn{6}{|l|}{ IGF-II [ng/ml] } \\
\hline Mean \pm SE & $798.7 \pm 40.00$ & $853.1 \pm 57.07$ & $887.4 \pm 43.05$ & $883.4 \pm 63.53$ & $781.7 \pm 36.70$ \\
\hline $95 \%$ CI of mean & $715.2-882.2$ & $731.5-974.8$ & $799.7-975.0$ & $755.1-1012$ & $695.2-868.2$ \\
\hline \multicolumn{6}{|l|}{ IGFBP2 [ng/ml] } \\
\hline Mean \pm SE & $663.2 \pm 86.2$ & $824.1 \pm 101.1$ & $926.6 \pm 137.7$ & $920.6 \pm 84.98$ & $922.3 \pm 143.7$ \\
\hline $95 \%$ CI of mean & $483.3-843.2$ & $608.7-1040$ & $648.5-1209$ & $749.0-1092$ & $609.3-1235$ \\
\hline \multicolumn{6}{|l|}{ IGFBP3 $[\mu \mathrm{g} / \mathrm{ml}]$} \\
\hline Mean \pm SE & $4.12 \pm 0.19$ & $4.39 \pm 0.23$ & $3.92 \pm 0.19$ & $4.02 \pm 0.17$ & $3.59 \pm 0.1 * *$ \\
\hline $95 \% \mathrm{CI}$ of mean & $3.72-4.52$ & $3.90-4.88$ & $3.54-4.31$ & $3.68-4.36$ & $3.20-3.99$ \\
\hline \multicolumn{6}{|l|}{$\mathrm{ALS}[\mu \mathrm{g} / \mathrm{ml}]$} \\
\hline $\operatorname{Mean} \pm \mathrm{SE}$ & $15.39 \pm 1.02$ & $14.53 \pm 1.13$ & $13.26 \pm 0.86$ & $13.85 \pm 0.84$ & $12.15 \pm 0.94$ \\
\hline $95 \% \mathrm{CI}$ of mean & $13.27-17.52$ & $12.11-16.94$ & $11.53-15.02$ & $12.13-15.56$ & $10.10-14.19$ \\
\hline \multicolumn{6}{|l|}{ IGF-I/BP3 x 10-3 } \\
\hline Mean \pm SE & $47.32 \pm 2.99$ & $44.09 \pm 3.12$ & $45.76 \pm 2.45$ & $44.46 \pm 2.00$ & $39.00 \pm 3.87$ \\
\hline $95 \%$ CI of mean & $41.08-53.56$ & $37.45-50.73$ & $41.19-50.34$ & $40.42-48.50$ & $30.55-47.44$ \\
\hline
\end{tabular}

$* \mathrm{p}<0.01$ as compared to group $\mathrm{I}, * * \mathrm{p}<0.02$ as compared to group II

III), 42 patients between 65 and $<75$ years (range 65 to 74 , group IV) and 13 patients 75 or more years (range 75 to 88 years, group V). The mean value of BMI was $25.7 \pm 0.35 \mathrm{~kg} / \mathrm{m}^{2}$, with the values below $22 \mathrm{~kg} / \mathrm{m}^{2}$ in 26 patients, between 22 and $25 \mathrm{~kg} / \mathrm{m}^{2}$ in 48 patients, between 25 and $30 \mathrm{~kg} / \mathrm{m}^{2}$ in 49 patients and above $30 \mathrm{~kg} / \mathrm{m}^{2}$ in 21 patients. BMI below $20 \mathrm{~kg} / \mathrm{m}^{2}$ or serum albumin level below $33 \mathrm{~g} / \mathrm{L}$ was accepted as a limit of malnutrition. Although such low values of albumin were noted in $5.6 \%$ of patients and such a low BMI in $4.7 \%$ of patients, none of the studied patients had both, very low albumin level and very low BMI.

In all studied patients, plasma levels of IGF-I (RIA, Biosource, Belgium), IGF-II and IGFBP3 (IRMA, Diagnostic Systems Laboratory, USA), IGF-BP2 (RIA, Diagnostic Systems Laboratory, USA), and acid labile subunit (ALS) (ELISA, Diagnostic Systems Laboratory, USA) were measured in serum samples before and one, six and twelve months after the surgery. Morning venous blood samples were taken after overnight fasting. Each blood sample was centrifuged within no more than 60 minutes after collection and serum was immediately separated, frozen and stored at $-20^{\circ} \mathrm{C}$ until assayed, but no longer than 4 months. Each serum sample was divided into eight portions to avoid refreezing. All pre-analytical steps were strictly controlled. Sensitivity of the assays was as follows: $8.7 \mathrm{ng} / \mathrm{ml}$ for IGF-I, $12.0 \mathrm{ng} / \mathrm{ml}$ for IGFII, $0.03 \mathrm{ng} / \mathrm{ml}$ for free IGF, $21.0 \mathrm{ng} / \mathrm{ml}$ for IGFBP2, $0.5 \mu \mathrm{g} / \mathrm{ml}$ for IGFBP3 and $0.7 \mu \mathrm{g} / \mathrm{ml}$ for ALS. The intra- and inter-assay coefficients of variations for each measurement were $<8 \%$ and $<10 \%$, respectively. Serum albumin level was determined by dry chemistry method (Vitros 950, Johnson \& Johnson).

\section{Statistical analysis}

The data were presented in the form including typical statistics (mean, SE, and 95\% CI). For each patient the concentrations of all measured parameters were also expressed as the ratio to albumin level (IGFs/alb, IGFBPs/alb). To evaluate the differences between the groups for every parameter, a repeated measurement one-way ANOVA test was performed. The statistical significant difference between the groups was calculated by using unpaired Student's t-test (the determinants of all the parameters studied were normally distributed). The correlations were expressed as Pearson's coefficient. A twotailed $p$ value of $\leq 0.05$ was accepted as indicating statistical significance. All statistical analyses were performed with Graph Pad PRISM 4.0.

\section{RESULTS}

IGF-I, IGF-II, IGFBP2, IGFBP3, and ALS in colon cancer patients before surgery

Before surgery a statistically significant negative correlation was found between the age and the concentrations of IGF-I $(p<0.01)$, IGFBP3 $(p<0.04)$ and ALS $(p<0.02)$, and positive correlation between age and IGFBP2 $(\mathrm{p}<0.05)$. The highest mean values of IGF-I concentration (and higher 95\% CI of mean) were found for groups I and II before surgery. In group III and group IV patients these values were insignificantly lower as compared to group I and group II. A significant difference between the mean levels of IGF-I was only between groups I and V $(\mathrm{p}<0.01)$ (Tab. 2; Fig. 1A). Similar trend of 
Figure 1. Serum concentration of IGF-I (A) and IGF-II (B) as well as the ratio of IGF-I to albumin (a) and the ratio of IGF-II to albumin (b) in colon cancer patients before surgery (open bars), one month after surgery (black bars) and six months after surgery (grey bars) in relation to patients age. ${ }^{*} \mathbf{p}<0.001, \# \# p<0.05$, as compared to the corresponding values before surgery.

A

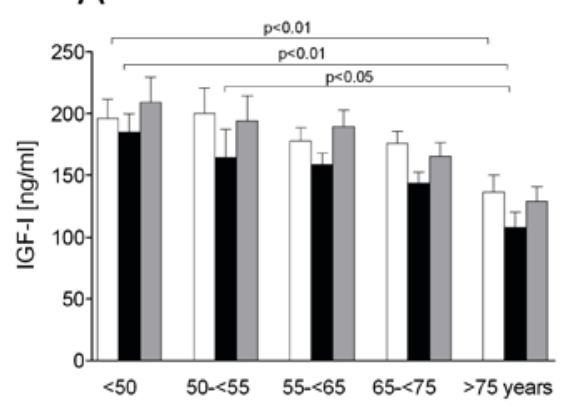

B

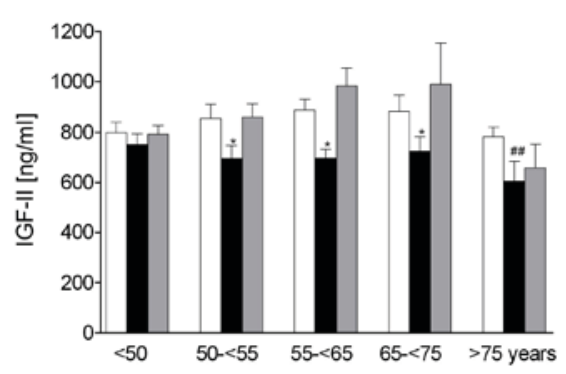

changes was observed for the mean values of IGFBP3 and ALS, but without significant differences between the groups studied (Fig. 2A, 2B). The mean values of IGF-II and IGFBP2 concentration did not differ with age, although in the case of IGFBP2 the lowest values were noted for group I.

IGF-I, IGF-II, IGFBP2, IGFBP3, and ALS in colon cancer patients one and six months after surgery

One month after surgery a decrease in the mean values of IGF-I, IGF-II, IGFBP3 and ALS was noted for all age groups as compared to the corresponding values before surgery, with the lowest decrease (5-9\%, on average) for group I and the highest (20-30\%, on average) for group V (Fig. 1A, 1B; Fig. $2 A, 2 B)$. However, no statistically significant differences were noted between the mean values of IGF-I one month after surgery and the corresponding values before surgery. When analyzing all the patients as one group, a decrease of mean IGF-I level after surgery, as compared to the value before surgery, was statistically significant $(p<0.001)$. One month after surgery the mean value of IGF-I concentration for group $\mathrm{V}$ was significantly lower as compared to group I and group II. In contrast, the mean values of IGFBP3 and ALS one month after surgery were significantly lower for all the groups except group I (Fig. 2A, 2B), as compared to the values before surgery. The mean levels of ALS one month after surgery were significantly lower in groups III $(\mathrm{p}<0.03)$, IV $(\mathrm{p}<0.02)$ and V $(p<0.002)$ as compared to the value noted for group I. Six and twelve months after surgery the mean concentrations of IGF-I, IGF-II, IGFBP3 and ALS did not differ from the respective values before surgery. The mean values obtained 12 months

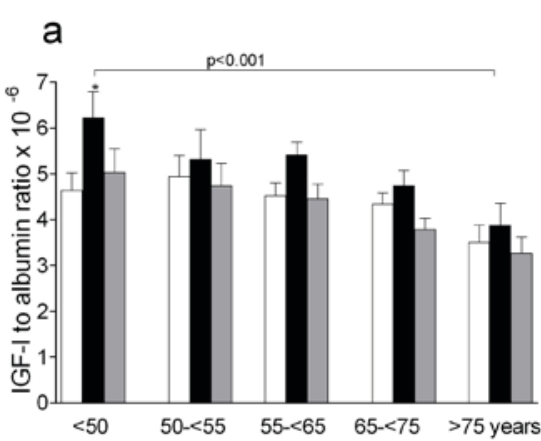

b

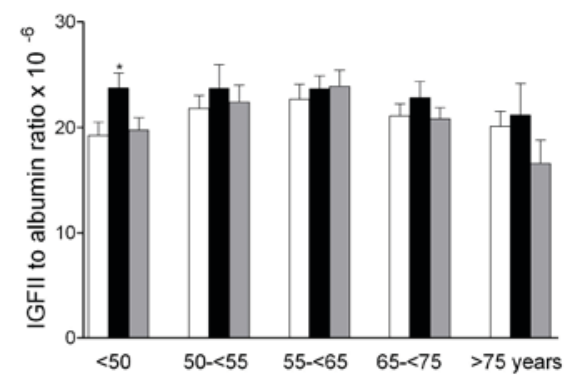

after surgery are not shown in Fig. 1, 2 and 3 for none of the parameters measured because $33.3 \%$ of the patients died within one year.

Except for group I, one month after surgery the mean levels of IGFBP2 had higher values as compared to the corresponding values before surgery, but significant differences were only for groups III and IV ( $\mathrm{p}<0.001$ for both cases) (Fig. 3A). The mean values for groups II, III, IV and V were significantly higher as compared to the value obtained for group I ( $\mathrm{p}<0.001$ 0.005) (Fig. 3A). Six and twelve months after surgery the mean values did not differ from the corresponding values noted before surgery.

\section{IGF-I to IGFBP3 ratio}

Regardless of the group studied and the time of observation, no differences between the mean values of IGF-I/IGFBP3 ratio were observed.

The ratio of IGF-I, IGF-II, IGFBP2, IGFBP3 and ALS levels to albumin

Fig. $1 a$ and $1 b$, Fig. $2 a$ and $2 b$ and Fig. $3 a$ present the mean values of IGFs and IGFBPs level expressed as the ratio to albumin (IGFs/alb, IGFBPs/alb) in relation to age and time of observation. One month after surgery, unlike the changes in the mean values of concentration, the mean values of IGF-I/alb, IGF-II/alb, IGFBP3/alb and ALS/alb were higher than or did not differ from the values obtained before surgery. A significant difference was found only in the case of IGF-I/alb and IGF-II/ alb in group I (Fig. 1a, 1b). Also, the mean value of IGF-I/ alb obtained for group I after surgery was significantly higher 
Figure 2. Serum concentration of IGFBP3 (A) and ALS (B) as well as the ratio of IGFBP3 to albumin (a) and the ratio of ALS to albumin (b) in colon cancer patients before surgery (open bars), one month after surgery (black bars) and six months after surgery (grey bars) in relation to patients age. ${ }^{\mathrm{p}}<0.001, \# \mathrm{p}<0.005, \& \& \mathrm{p}<0.002$, as compared to the corresponding values before surgery.
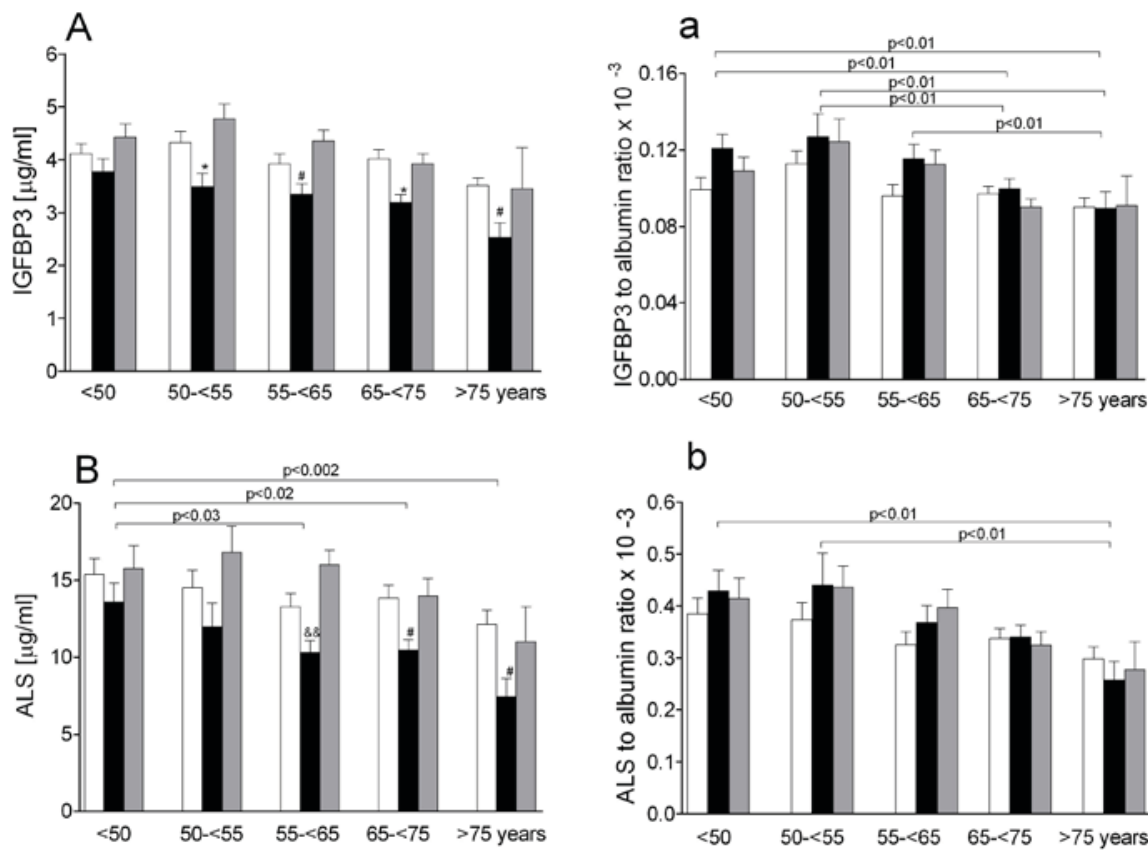

b

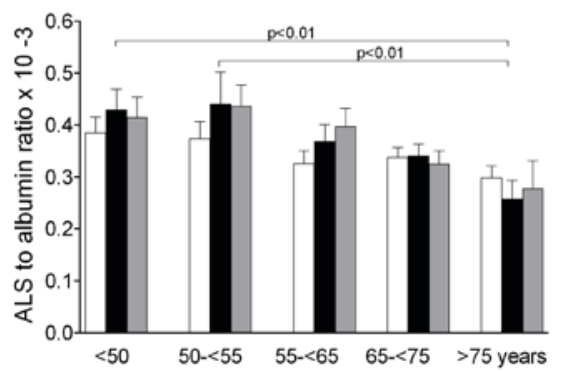

Figure 3. Serum concentration of IGFBP2 (A) and the ratio of IGFBP2 to albumin (a) in colon cancer patients before surgery (open bars), one month after surgery (black bars) and six months after surgery (grey bars) in relation to patients age. * $<<0.001$, as compared to the corresponding values before surgery.

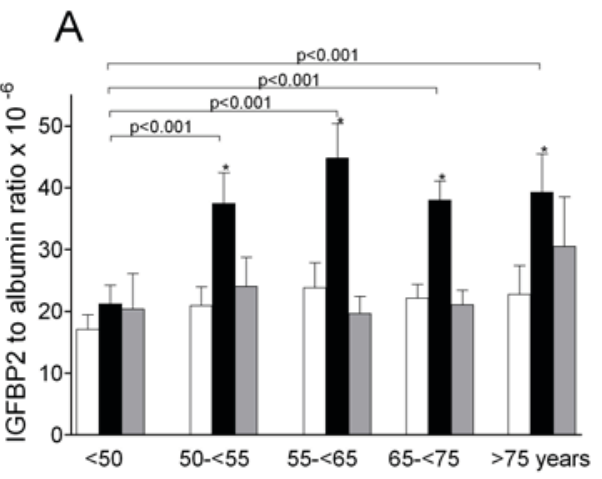

as compared to the mean value noted for group $\mathrm{V}(\mathrm{p}<0.001)$. No changes for IGF-II/alb ratio were found at any time of observation. One month after surgery significant differences in mean values were noted for IGFBP3/alb (Fig. 2a). The mean values of this ratio were significantly higher in groups I and II as compared to groups IV and $\mathrm{V}(\mathrm{p}<0.01$ in all cases), as well as in group III vs. group V $(p<0.001)$. For ALS/alb significantly higher mean values one month after surgery were noted for groups I and II as compared to those for group V $(\mathrm{p}<0.01$ in both cases) (Fig. 2b).

The changes observed for IGFBP $2 /$ alb ratio were similar to those of IGFBP2 concentration. An exception made a statistically significant increase in the mean values of IGFBP2/ alb observed for groups II-V $(\mathrm{p}<0.001)$, but not for group I (Fig. 3a), as compared to the corresponding values before surgery. Also the values for groups II-V were significantly

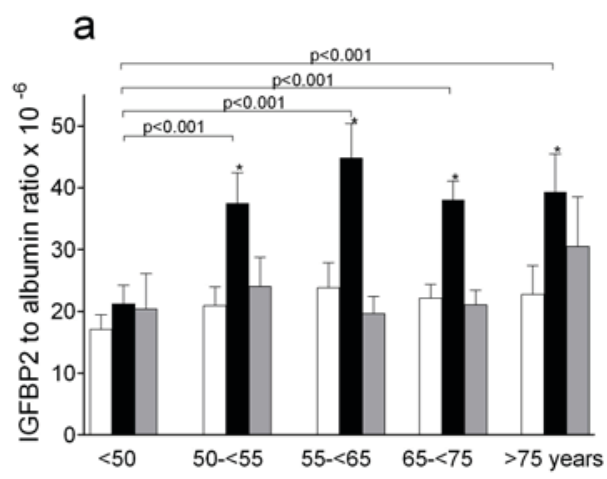

higher than those for group I $(p<0.001)$. For all the groups, six and twelve months after surgery the mean values were almost identical to the corresponding values noted before surgery.

\section{DISCUSSION}

Many clinical, laboratory, as well as, epidemiological studies, link the IGF system with colorectal cancer [14-16]. Unfortunately, most of the data are difficult to compare not only due to the complexity of the IGF system. There are other aspects which should be taken into consideration before the clearly cut statement on the role of IGF system in cancer risk and progression can be made. Looking from the laboratory point of view, two problems must be solved: the IGFs and IGFBPs reference intervals for adult population and the analytical 
aspects of the measurement of IGF axis components. The latter problem stems from the fact that most components of human endocrine system, including IGFs and IGFBPs, are measured by immunochemical methods which differ in precision and accuracy, as well as susceptibility to many interferences. Looking from the clinical point of view, physical condition of the patient, accompanying diseases, hormonal status, stage of the disease, tumor localization, medical treatment etc. should be taken into account. Any relation of the concentration of the analytes to age must also be considered. In another words, the question of "when" and "how" the analyte is measured must first be evaluated.

Age-dependent changes of IGF-I and IGFBP3 in healthy peoples of older age have been already published $[10,11,17]$. The same trend emerges from the results of the present study: a decrease in IGF-I, IGFBP3 and ALS concentrations with age can also be observed in colon cancer patients. It is only the trend which can be considered, because, as for almost all components of the endocrine system, it is not quite appropriate to do any comparison between the studies using population based reference intervals. Another problem in the evaluation of the role of IGF axis system in colorectal cancer lies in the nature of immunochemical methods. In addition to poor comparability between different reagent kits, the problem of heterogeneity of the measured components of IGF system and the known problem of interferences from the presence of heterophilic antibodies has never been carefully studied. This problem is important, because the presence of different autoantibodies and/or heterophilic antibodies in serum or plasma samples increases with age.

Another problem with proper interpretation of the results of the determination of IGF system components is connected with clinical state of patients. Many critical illnesses are responsible for changes in endocrine system. It is known that surgery is one of the conditions causing a decrease in IGF-I, IGFBP3 and ALS concentrations [18]. Caloric restriction does not affect IGFBP3 or IGFBP3 proteolytic activity but causes a decrease in IGF-I levels [19] as it was also seen in the present study one month after surgery. According to the published data, low levels of IGFBP3 detected in advanced malignancy may be a consequence of an increased tumor driven proteolysis [20]. IGFBP3 degraded by proteolysis has a reduced affinity for IGF-I and IGF-II, but its ability to form ternary complexes with ALS is fully maintained. Acid-labile subunit (ALS) does not by itself bind IGF-I, but is necessary to form the complex with IGF-I-IGFBP3 and, like IGF-I and IGFBP3, is primarily under control of the growth hormone (GH) [21,22]. Except in critically ill patients $[23,24]$, ALS is relatively independent of the mechanisms known to influence the secretion of IGF-I and IGFBP3 [25]. ALS also increases the affinity of IGF-I to degraded, but not intact, IGFBP3 [26].

The observed decrease in IGF-I, IGF-II, IGFBP3 and ALS levels one month after surgery was not seen when the results were presented as the ratio to albumin. This suggests that the changes are due to nonspecific effects of surgery. Together with a decrease of albumin, a negative acute phase protein, the observed tendency might be due not only to the diminished synthetic function of the liver but also to hemodilution. Our data suggest that in the colon cancer patients both IGFBP3/ alb and ALS/alb values were not influenced by surgery, although extensive proteolysis of IGFBP3 has been reported in critically ill patients, as well as following major abdominal surgery [26-28]. This may suggest that an increase in IGF-I/ alb observed one month after surgery is not related to the failure of forming ternary complexes with IGFBP3 and ALS. Synthesis of IGF-II also takes place in the liver but is not tightly regulated by GH. This explains why almost no changes in IGF-II concentration were seen in our patients in relation to age and time of observation. In older colon cancer patients (65 years or more) a significantly lower IGFBP3/alb and ALS/alb ratio one month after surgery as compared to the values noted in younger patients may be explained by general declining of endocrine function in older patients and/or the more frequent presence of inflammation.

In human colon cancer the amount of IGFBP2 in the circulation is often elevated [29]. This was also confirmed in our study. The mean level of IGFBP2 for all the studied patients was twice as high as compared to the laboratory reference range for healthy adults aged 55 to 75 years (data not shown). IGFBP2 is up-regulated in conditions such as starvation or trauma. This explains a significant increase in IGFBP2 concentration after surgery. Interestingly, the smallest increase one month after surgery was seen in the patients below 55 years of age and the value was significantly lower as compared to groups II-V. It was suggested that IGFBP-2 inhibits IGF-I and IGF-II action, so the lack of increase in IGFBP-2 one month after surgery in group I could be responsible for higher IGFs. The exact reason why this takes place only in young patients is not clear. From the clinical point of view it is known that in younger colon cancer patient the course of disease is more aggressive. It is tempting to speculate, that one of the reasons of it is the enhanced proteolysis of IGFBP 2 in younger patients which might lead to an increase in free IGF-I, having easier access to extravascular space. Increased bioavailability of IGF-I, with its mitogenic and antiapoptotic effects, may be one of the factors responsible for faster tumor progression at any stage [30]. It is not known whether this is the case only in younger colon cancer patients. It might be the case, because increased serum IGFBP1 and IGFBP2 are inversely associated with colorectal cancer risk [31].

\section{CONCLUSIONS}

The present study shows that in colon cancer patients the correlation between IGF-I, IGFBP3 and ALS exists regardless of the patient's age and time of observation, and that IGF-I, IGFBP3 and ALS decrease with age. It can be speculated that in patients below 50 years the lowest IGFBP2 together with 
the elevated IGF-I might be the reason of more aggressive course of the disease. Also, any conclusion concerning the relation of IGF system to the risk and/or progression of colon cancer should be considered separately for younger (below 50 years of age) and older patients.

\section{ACKNOWLEDGMENTS}

Grant/funding support: This work was supported by KBN grant No. 3 P05C 05024

Financial disclosures: none

\section{REFERENCES}

1. Ma J, Pollak NM, Giovannucci E, Chan JM, Tao Y, Hennekens CH, Stampfer MJ. Prospective study of colorectal cancer risk in men and plasma levels of insulin-like growth factor (IGF-I) and IGF-binding protein-3. J Natl Cancer Inst. 1999 Apr;91(7):620-5.

2. Longo VD, Finch CE. Evolutionary medicine: from dwarf model systems to healthy centenarians? Science. 2003 Feb;299(5611):1342-6.

3. Tatar M, Bartke A, Antebi A. The endocrine regulation of aging by insulin-like signals. Science. 2003 Feb;229(5611):1346-51.

4. Rajaram S, Baylink DJ, Mohan S. Insulin-like growth factor-binding proteins in serum and other biological fluids: regulation and functions. Endrocr Rev. 1997 Dec;18(6):801-31.

5. Holly J, Gunnell D, Davey Smith G. Growth hormone, IGF-I and cancer. Less intervention to avoid cancer? More intervention to prevent cancer. J Endocrinol. 1999 Sep;162(3):321-30.

6. Sandhu MS, Dunger DB, Giovannucci EL. Insulin, insulin-like growth factor-I (IGF-I), IGF binding proteins, their biologic interactions and colorectal cancer. J Natl Cancer Inst. 2002 Jul;94(13):972-80.

7. Firth SM, Baxter RC. Cellular actions of the insulin-like growth factor binding proteins. Endocr Rev. 2002 Dec;23(6):824-54.

8. Underwood LE, Thissen JP, Lemozy S, Ketelslegers JM, Clemmons DR. Hormonal and nutritional regulation of IGF-I and its binding proteins. Horm Res. 1994;42(4-5):145-51.

9. Nam SY, Lee EJ, Kim KR, Cha BS, Song YD, Lim SK, Lee HC, Huh KB. Effect of obesity on total and free insulin-like growth factor (IGF-I) and their relationship to IGF-binding protein (BP)-1, IGFBP2, IGFBP3, insulin and growth hormone. Int J Obes Relat Metab Disord.1997 May;21(5):355-9.

10. Janssen JA, Stolk RP, Pols HA, Grobbee DE, de Jong FH, Lamberts SW. Serum free IGF-I, total IGF-I, IGF-BP1 and IGF-BP3 levels in an elderly population: relation to age and sex steroid levels. Clin Endocrinol. 1998 Apr;48(4):471-8.
11. Friedrich $\mathrm{N}$, Alte $\mathrm{D}$, Völzke H, Spilcke-Liss E, Lüdemann J, Lerch MM, Kohlmann T, Nauck M, Wallaschofski H. Reference ranges of serum IGF-I and IGFBP- levels in a general adult population: Results of the Study of Health in Pomerania (SHIP). Growth Horm IGF Res. 2008 Jun;18(3):228-37.

12. Hutter RV, Sobin LH. A universal staging system for cancer of the colon and rectum. Arch Pathol Lab Med. 1986 May;110(5):367-8.

13. Greene FL, Compton CC, Fritz AG, Shah JP, Winchester DP. AJCC cancer staging atlas. 1st ed. New York: Springer; 2006.

14. Donowan EA, Kummar S. Role of insulin-like growth factor-1R system in colorectal cancinogenesis. Crit Rev Oncol Hematol. 2008 May;66(2):91-8.

15. Davies M, Gupta S, Goldspink G, Winslet M. The insulin-like growth factor system and colorectal cancer: clinical and experimental evidence. Int J Colorectal Dis. 2006 Apr;21(3):201-8.

16. Durai R, Yang W, Gupta S, Seifalian AM, Winslet $\mathrm{MC}$. The role of the insulin-like growth factor system in colorectal cancer: review of current knowledge. Int J Colorectal Dis. 2005 May;20(3):203-20.

17. Gomez JM, Maravall FJ, Gomez N, Navarro MA, Casamithana R, Soler J. The IGF-I system components concentrations that decrease with aging are lower in obesity in relationship to body mass index and body fat. Growth Horm IGF Res. 2004 Apr;14(2):91-6.

18. Arosio M, Garrone S, Bruzzi P, Faglia G, Minuto P, Barreca A. Diagnostic values of the acid-labile subunit in acromegaly: evaluation in comparison with insulin-like growth factor (IGF), and IGF-binding protein-1, -2 and -3. J Clin Endocrinol Metab. 2001 Mar;86(3):1091-8.

19. Smith WJ, Underwood LE, Clemmons DR. Effects of caloric or protein restriction on insulin-like growth factor-I (IGF-I) and IGF-I binding proteins in children and adults. J Clin Endocrinol Metab. 1995 Feb;80(2):443-9.

20. Baciuchka M, Remacle-Bonnet M, Garrouste F, Favre R, Sastre B, Pommier G. Insulin-like growth factor (IGF)-binding protein-3 (IGFBP-3) proteolysis in patients with colorectal cancer: possible association with the metastatic potential of the tumor. Int J Cancer 1998 Oct;79(5):460-7.

21. Ooi GT, Cohen FJ, Tseng LY, Rechler MM, Boisclair YR. Growth hormone stimulates transcription of the gene encoding the acid-labile subunit (ALS) of the circulating insulin-like growth factor-binding protein complex and ALS promoter activity in rat liver. Mol Endocrinol. 1997 Jun;11(7):997-1007.

22. Dai J, Baxter RC. Regulation in vivo of the acid labile subunit of the rat serum insulin-like growth factor-binding protein complex. Endocrinology. 1994 Dec;135(6):2335-41.

23. Barreca A, Ketelslegers JM, Arvigo M, Minuto F, Thissen JP. Decreased acid-labile subunit (ALS) levels by endotoxin in vivo and by interleukin- $1 \beta$ in vitro. Growth Horm IGF Res. 1999 Jun;8(3):217-23. 
24. Baxter RC, Hawkers FH, To C, Stewart PM, Holman SR. Thirty-day monitoring of insulin-like growth factors and their binding proteins in intensive care unit patients. Growth Horm IGF Res. 1998 Dec;8(6):455-63.

25. Barreca AM, Voci A, Lee PD, Arvigo M, Ghigliotti V, Fugassa E, Giordano G, Minuto F. Effect of the somatostatin analogue, octreotide, and of other hormones on the release of the acid-labile subunit (ALS) of the $150 \mathrm{kDa}$ complex by rat hepatocyte in primary culture. Eur J Endocrinol. 1997 Aug;137(2):193-9.

26. Baxter RC, Skriver L. Altered ligand specificity of proteolysed insulin-like growth factor binding protein-3. Biochem Biophys Res Commun. 1993 Nov;196(3):1267-73.

27. Bang P. Serum proteolysis of IGFBP-3. Prog Growth Factor Res. 1995;6(2-4):285-92.

28. Skjaerbaek C, Frystyk J, Orskov H, KissmeyerNielsen P, Jensen MB, Laurberg S, Moller N, Flyvbjerg A. Differential changes in free and total insulin-like growth factor I after major, elective abdominal surgery: the possible role of insulin-like growth factor-binding protein-3 proteolysis. J Clin Endocrinol Metab. 1998 Jun;83(7):2445-9.
29. el Atiq F, Garrouste F, Remacle-Bonnet M, Sastre B, Pommier G. Alterations in serum levels of insulinlike growth factors and insulin-like growth-factor-binding proteins in patients with colorectal cancer. Int J Cancer. 1994 May;57(4):491-7.

30. Yu H, Rohan T. Role of the insulin-like growth factor family in cancer development and progression. J Natl Cancer Inst. 2000 Sep;92(18):1472-89.

31. Kaaks R, Toniolo P, Akhmedkhanov A, Lukanova A, Biessy C, Dechaud H, Rinaldi S, Zeleniuch-Jacquotte A, Shore RE, Riboli E. Serum C-peptide, insulin-like growth factor (IGF-I), IGF-bilnding proteins, and colorectal cancer risk in women. J Natl Cancer Inst. 2000 Oct;92(19):592-600. 